\title{
The judgment of Paris
}

\author{
Shaun McCann ${ }^{1}$
}

Received: 13 August 2018 / Accepted: 13 August 2018 / Published online: 15 October 2018

c) Springer Nature Limited 2018

'All that glisters is not gold'.

William Shakespeare. The Merchant of Venice,

The judgment of Paris means many different things to different people. The origin of the saying seems to be Greek mythology. The contest between the three beauties, often but not always depicted naked, was said to have initiated the Trojan War. Paris (a Trojan mortal) was asked, by Zeus, to judge who was the most beautiful of the three, Hera, Aphrodite, and Athena. Paris was unable to decide so he asked the girls to take off their clothes so that he could get a good look. Aphrodite promised Paris the most beautiful girl in the world, Helen. Unfortunately Helen was the wife of Menelaus and so this was the origin of the Trojan War. The rest, as they say, is history.

A different "judgment of Paris" happened in medicine. The first descriptions of acquired immune deficiency syndrome (AIDS) in the early 1980s referred to a syndrome known as gay-related immune deficiency. It subsequently became clear that the syndrome could affect heterosexual individuals and the name became AIDS. The syndrome was characterized by profound T-cell deficiency and bizarre infections such as Pneumocystis jiroveci pneumonia formerly known as Pneumocystis carinii pneumonia. Many people developed AIDS after treatment with "factor concentrates" for the treatment of hemophilia and blood transfusions for divers indications. In 1984 the linkage between AIDS and a lentiretroviral infection was made and

Shaun McCann

shaunrmccann@gmail.com

1 Trinity College, Haematology Emeritus, University of Dublin, Dublin, Ireland a race began to identify the virus that caused AIDS. The two main players in the race were Professor Luc Montagnier and his laboratory in Paris and Professor Robert Gallo and his laboratory at the National Institutes of Health in Bethesda. When the virus that caused AIDS was discovered the battle became serious fueled by claim and counterclaim. In 2008 the Nobel Prize for Medicine or Physiology was shared between the virologists Harald zur Hausen (human papillomavirus and human cervical cancer), Françoise BarréSinoussi, and Luc Montagnier for the discovery of the human immunodeficiency virus (HIV). "The judgment of Paris"? Happily since the introduction of nucleac acid testing, the spread of HIV via blood transfusion is rare.

Of course there is a 'Judgment of Paris in the wine world also. In 2005 George M Taber wrote a book: 'Judgment of Paris: California vs France and the Historic 1976 Paris Tasting that Revolutionized Wine'. The "blind tasting" was the brainchild of Steven Spurrier, an English man with a wine shop/school in Paris, L'Académie du Vin. Until then Californian wine was believed by the "cognoscenti" to be far inferior to French wine. Spurrier, in what he thought would be a rather low-key affair, arranged a blind tasting in Paris of French and Californian wines with George Taber (reporter and editor with Time magazine) as a "referee". Blind tasting of wine means that the judges do not know the origin of the wines they are tasting as the labels/bottles are disguised. To everybody's amazement the Californian wines came out as winners, the Chardonnay from Chateau Montelena (Napa valley) coming first in the white wine category and the Cabernet Sauvignon from Stag's Leap wine cellars, also in Napa valley, in the red category (beating the Château Mouton Rothschild)! The result of this blind tasting changed the "wine world" forever. I am told that one of the French judges, Odette Kahn, was so disgusted with the result that she requested the return of her tasting notes. Spurrier refused and apparently she never spoke to him again.

My wife and I visited Chateau Montelena a few years ago when I attended the annual ASH meeting in San Francisco. In spite of the rain we got a warm welcome (the 
owner, Jim Barrett was Irish) and although we don't drink Chateau Montelena regularly we enjoyed the tasting.

We met Steven Spurrier recently in Castellina in Chianti where he was signing his book "A Way of Life" and allowing us to taste his latest offering of sparkling wine from his vineyard in England. Excellent!

Double-blind clinical trials (the participant and the clinician/data collectors are unaware of the treatment the participant receives) are conducted in order to minimize the chance of prejudice in the result. The first clinical trial was carried out by James Lind, who served as a surgeon's mate in the Royal Navy in the late 1730s, when he treated scurvy with limes/lemons with great success. We are probably a little more sophisticated now but subgroup analyses based on molecular data may supercede larger double-blind studies.

Photographs:

The Judgment of Paris. Peter Paul Rubens. 1632-1635

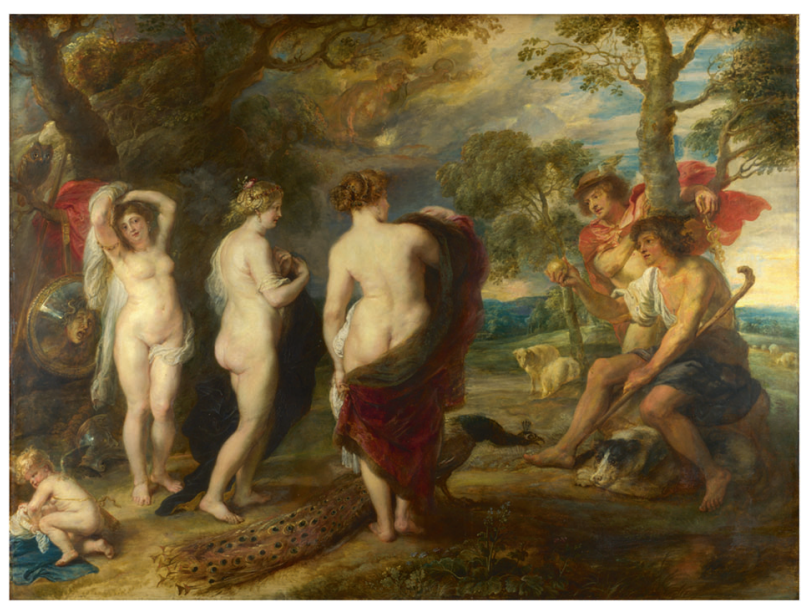

Steven Spurrier at a book signing in Castellina in Chianti. August 2018

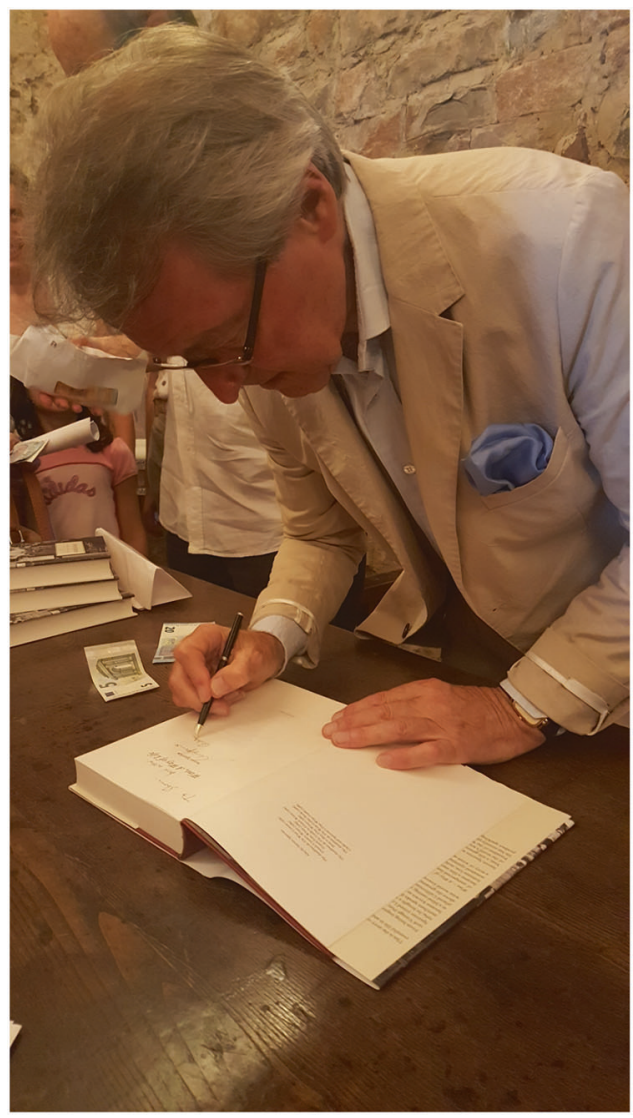

\section{Compliance with ethical standards}

Conflict of interest The author declares that he has no conflict of interest. 